\title{
Growth and chemical composition of the toxic dinoflagellate Gymnodinium galatheanum in relation to irradiance, temperature and salinity
}

\author{
Marianne V. Nielsen \\ Trondhjem Biological Station, The Museum, University of Trondheim, Bynesveien 46, N-7018 Trondheim, Norway
}

\begin{abstract}
Gymnodinium galatheanum Braarud shows optimum growth $\left(0.57 \mathrm{~d}^{-1}\right)$ at 20 to $24^{\circ} \mathrm{C}$ and $24 \% \mathrm{~S}$, within a temperature/salinity range of 7 to $24^{\circ} \mathrm{C}$ and 10 to $34 \% \mathrm{~S}$, respectively. The growth rate is significantly affected by temperature and salinity, but no temperature-salinity interaction is found. No photoinhibition is found below $500 \mu \mathrm{mol}$ photons $\mathrm{m}^{-2} \mathrm{~s}{ }^{1}$ Optimum irradiance for growth is $\sim 120 \mu \mathrm{mol}$ $\mathrm{m}^{-2} \mathrm{~s}^{-1}$, while the optimum for the growth-relevant $\mathrm{ch}$ l a-normalized C fixation rate is $>500 \mu \mathrm{mol} \mathrm{m}^{-2} \mathrm{~s}^{-1}$ This difference in optimum irradiance for the growth and photosynthetic rate is related to a decrease in the cellular chl a/carbon ratio with increasing irradiance. Carbon, nitrogen and phosphorus contents per cell are significantly affected by temperature, salinity and irradiance. The high and low P/C and N/P ratios, respectively, for nutrient saturated cells indicate that G. galatheanum has a large storage capacity for phosphorus.
\end{abstract}

KEY WORDS: Gymnodinium galatheanum - Toxic dinoflagellate Growth ecology Chemical composition

\section{INTRODUCTION}

An extensive bloom of Gymnodinum galatheanum associated with fish mortality was recorded in Walvis Bay, South Africa, in 1950 (Braarud 1959, Steemann Nielsen \& Aabye Jensen 1959). The fish mortalities in Walvis Bay were reported as recurrent events; however, it was not clear whether the fish mortalities were caused by toxic plankton, by anoxic conditions due to hydrogen sulphide release from the bottom sediments, by oxygen depletion due to algal respiration and/or decomposition of the bloom or by a combination of these factors (Copenhagen 1953, Pieterse \& Van Der Post 1967). Later studies in Walvis Bay (1964-1967) reported that G. galatheanum was one of 4 dinoflagellates that regularly cause red tide blooms in the bay; one of these blooms with high numbers of $G$. galatheanum was associated with fish mortality, whereas other blooms were not (Picterse \& Van Der Post 1967). G. galatheanum is also found in northern waters. Blooms have been recorded from the Oslofjord, Norway (Bjørnland \& Tangen 1979, K. Tangen pers. comm.) and it has been found along the southern coast of Norway (Dahl \& Yndestad 1985). G. galatheanum is occasionally found in the North Sea region as an accompanying species in blooms of the toxic dinoflagellate Gyrodinium aureolum (Larsen \& Moestrup 1989).

Recently Gymnodinium galatheanum cultures have been shown to have a negative effect on shell length growth of mussels (Nielsen \& Strømgren 1991) and to have lethal effects on juvenile cod (Nielsen 1993). These results and the field observations from Walvis Bay indicate that $G$. galatheanum, at least on some occasions, may produce a toxin.

Physiological indications exist that Gymnodinium galatheanum is closely related to the toxic dinoflagellate Gyrodinium aureolum. Both lack peridinin, which is found in most other dinoflagellates, and both possess chl $c_{3}$, characteristic of several bloom-forming prymnesiophytes (Johnsen \& Sakshaug 1993). They also possess the carotenoid 19'hexanoyl-oxy-fucoxanthin (Bjørnland \& Tangen 1979, Tangen \& Bjørnland 1981), indicating a common origin of their chloroplasts, and 
they differ from other studied dinoflagellate species by their almost complete lack of ability to take up $\mathrm{NO}_{3}{ }^{-}$ in the dark, except when $\mathrm{N}$-deficient (Paasche et al. 1984).

The growth ecology of Gymnodinium galatheanum has not previously been investigated (Bjergskov et al 1990); the present study was undertaken to determine this species' growth and chemical composition at different temperatures, salinities and irradiances.

\section{MATERIALS AND METHODS}

Gymnodinium galatheanum Braarud strain KT76E, used in the present study, was isolated in 1976 from the Oslofjord by Karl Tangen. Batch cultures were grown in $200 \mathrm{ml}$ glass bottles in K-medium (Keller et al. 1987), with $\mathrm{NaH}_{2} \mathrm{PO}_{4}(36.2 \mu \mathrm{M})$ as the phosphorus source. Filtered seawater (Trondheimsfjord, $120 \mathrm{~m}$ depth, off the Biological Station), when necessary diluted with distilled, deionized water to adjust the salinity, was pasteurized for $3 \mathrm{~h}$ at $80^{\circ} \mathrm{C}$ before enrichment. Light was supplied by banks of fluorescent tubes (Phillips TL 20W/55 de luxe and TL 40W/ 55 de luxe).

Growth and chemical composition of Gymnodinium galatheanum were studied (1) as an effect of irradiance (20 to $480 \mu \mathrm{mol} \mathrm{m} \mathrm{m}^{-2} \mathrm{~s}^{-1}$ ) at constant temperature and salinity $\left(15^{\circ} \mathrm{C}, 34 \% \mathrm{~S}\right)$ and (2) as an effect of temperature and salinity in a factorial design with 30 different combinations of temperature $\left(7,10,15,20,24^{\circ} \mathrm{C}\right)$ and salinity $(10,14,19,24,29,34 \% \mathrm{~S})$ at constant irradiance $\left(255 \mu \mathrm{mol} \mathrm{m} \mathrm{m}^{-2} \mathrm{~s}^{-1}\right)$. Irradiance was measured inside water-filled flasks with a QSL-100 photometer (Spherical sensor, Biospherical Instruments, Inc.). The different irradiances $(20,25,50,66,80,100,116,121$, $183,232,249,315,481 \mu \mathrm{mol} \mathrm{m} \mathrm{m}^{-2} \mathrm{~s}^{-1}$ ) were obtained by means of neutral nylon screens. Daylength was $18 \mathrm{~h}$. Temperatures were kept within $0.5^{\circ} \mathrm{C}$. Salinity was measured in a CSIRO inductively coupled salinometer. Transfers to the highest and lowest temperatures and salinities were gradual.

Before the experiments were begun, the algae were acclimated to the experimental conditions for at least 3 generations. The algae were kept in the exponential growth phase at concentrations ranging from $\sim 1$ to 60 cells $\mu^{-1}\left(\leq 27 \mu \mathrm{g} \mathrm{chl} \mathrm{a} \mathrm{l}^{-1}\right)$. The fastest-growing cultures were regularly diluted with $\mathrm{K}$-medium. In the irradiance experiment, 1 culture was grown at each irradiance, and the experiment repeated from new inocula. In the temperature-salinity experiment cultures were grown in duplicate. In vivo fluorescence was measured (Turner Designs) 2 or 3 times per week, and growth curves were generated based on a minimum of 5 measurements
When the cultures approached the upper concentration limit within the exponential phase, duplicate samples were harvested (pressure $>-200 \mathrm{mb}$ ) on $2.5 \mathrm{~cm}$ pre-ignited $\mathrm{GF} / \mathrm{C}$ filters for analysis of algal carbon, nitrogen, phosphorus and, in the irradiance experiment, also algal chl a. Cell density was determined with a Nageotte slide. Algal carbon and nitrogen were analyzed on a Carlo Erba NA 1500 elemental analyzer. Total phosphorus was determined as orthophosphate after digestion with acid persulphate (Koroleff 1976, as modified by Olsen \& Østgaard 1985).

Based on the specific growth rate, $\mu\left(\mathrm{d}^{-1}\right)$, the growth-relevant chl a-normalized $C$ fixation rate, ${ }^{\mu} P^{\mathrm{B}}$ ( $\mathrm{mg} \mathrm{C} \mathrm{mg}^{-1}$ chl $a \mathrm{~h}^{-1}$ ), was calculated by multiplying the growth rate by the corresponding value of cellular carbon divided by cellular chl $a$ and light hours

$$
\mu p^{\mathrm{B}}=\mu \cdot \frac{\mathrm{C}}{\operatorname{chl} a} \cdot \frac{1}{D}
$$

In analogy with the photosynthesis-irradiance equation (see Platt et al. 1980), the relation of $\mu$ and ${ }^{\mu} P^{\mathrm{B}}$ to irradiance is described by the equation:

$$
P=P_{m}\left[1-\exp \left(-\alpha E_{\circ} / P_{m}\right)\right]
$$

where $P$ is $\mu$ or ${ }^{\mu} P^{\mathrm{B}}$, respectively; $P_{\mathrm{m}}$ is maximum rate; $E_{0}$ is irradiance; and $\alpha$ is the initial slope. ${ }^{\mu} P^{\mathrm{B}}$ differs from the chl $a$-normalized photosynthetic rate $\left(p^{B}\right)$ of $P$ vs $E$ curves in that ${ }^{\mu} P^{\mathrm{B}}$ here represents the net production of light-adapted algae.

\section{RESULTS}

\section{Effect of irradiance}

For Gymnodinium galatheanum the maximum specific growth rate $\left(0.28 \mathrm{~d}^{-1}\right)$ at $15^{\circ} \mathrm{C}$ and $34 \% \mathrm{~S}$ was found at an irradiance $\left(E_{0}\right)$ of about $120 \mu \mathrm{mol} \mathrm{m}^{-2} \mathrm{~s}^{-1}$, the initial slope $(\alpha)$ was $0.008\left(\mu \mathrm{mol} \mathrm{m} \mathrm{m}^{-2} \mathrm{~s}^{-1}\right) \mathrm{d}^{-1}$ and the index of light saturation $\left(I_{k}=\mu_{\mathrm{m}} / \alpha\right)$ was $37 \mu \mathrm{mol} \mathrm{m} \mathrm{m}^{-2} \mathrm{~s}^{-1}$ (Fig. $1 \mathrm{~A}$ ). The $\mathrm{C}$ fixation rate at light saturation, ${ }^{\mu} P^{\mathrm{B}}{ }_{\mathrm{m}}$ was $3.1 \mathrm{mg} \mathrm{C}(\mathrm{mg} \mathrm{chl} a)^{-1} \mathrm{~h}^{-1}$, the initial slope $\left({ }^{\mu} \alpha^{\mathrm{B}}\right)$ was $0.019 \mathrm{mg} \mathrm{C}(\mathrm{mg} \mathrm{chl} \mathrm{a})^{-1}\left(\mu \mathrm{mol} \mathrm{m} \mathrm{m}^{-2} \mathrm{~s}^{-1}\right)^{-1} \mathrm{~h}^{-1}$ and the

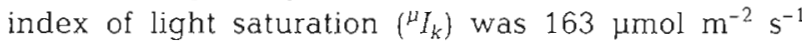
(Fig. $1 \mathrm{~B}$ ) ${ }^{\mu P^{\mathrm{B}}}{ }_{\mathrm{m}}$ was found at an irradiance of $>500 \mu \mathrm{mol}$ $\mathrm{m}^{-2} \mathrm{~s}^{-1}$ No photoinhibition was found below $500 \mu \mathrm{mol}$ $\mathrm{m}^{-2} \mathrm{~s}^{-1}$ (Fig. 1A, B). G. galatheanum was observed to survive for several months in the stationary phase

Cellular chl $a$ and the chl $a / C$ ratio decreased significantly with increasing irradiance, and cellular carbon and nitrogen decreased significantly with increasing irradiance below the optimum irradiance for growth $\left(120 \mu \mathrm{mol} \mathrm{m} \mathrm{m}^{-2} \mathrm{~s}^{-1}\right)$, while cellular carbon, nitrogen and phosphorus increased significantly with increasing irradiance above $120 \mu \mathrm{mol} \mathrm{m} \mathrm{m}^{-2} \mathrm{~s}^{-1}$ (Fig. 2 

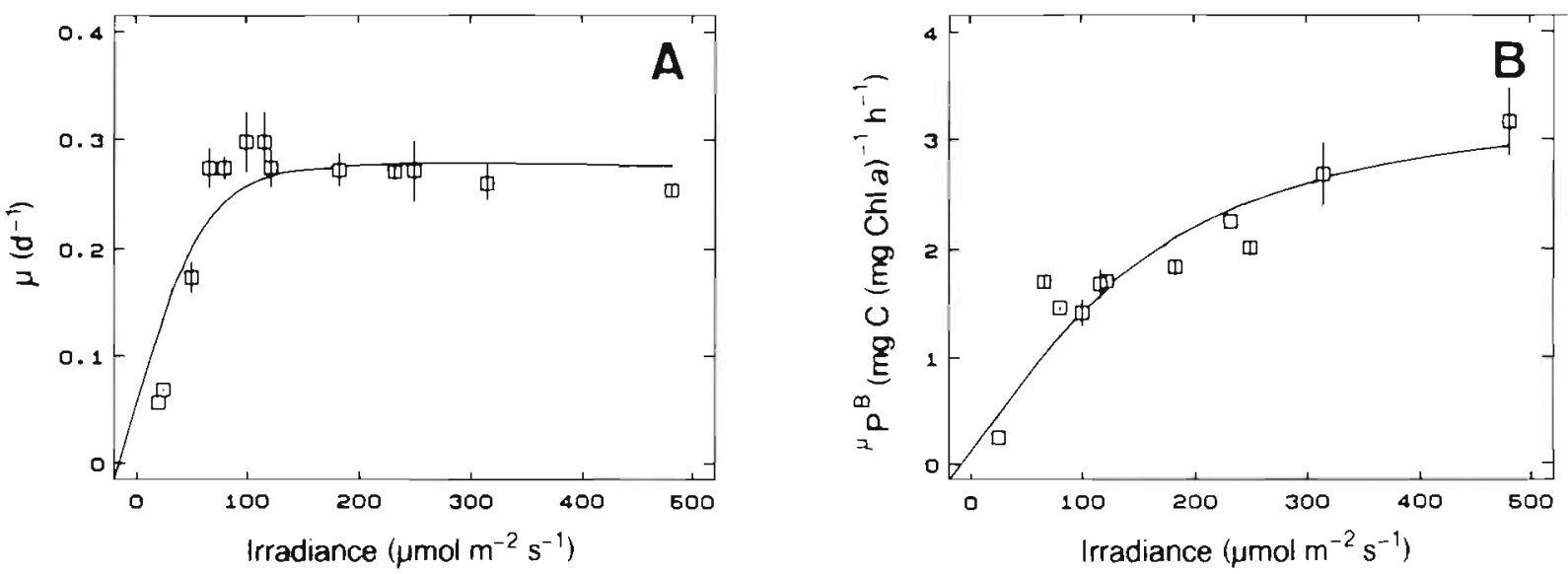

Fig. 1. Gymnodinium galatheanum. (A) Specific growth rate and (B) ${ }^{\mu} P^{\mathrm{B}}$ related to irradiance. Means $\pm \mathrm{SE}$
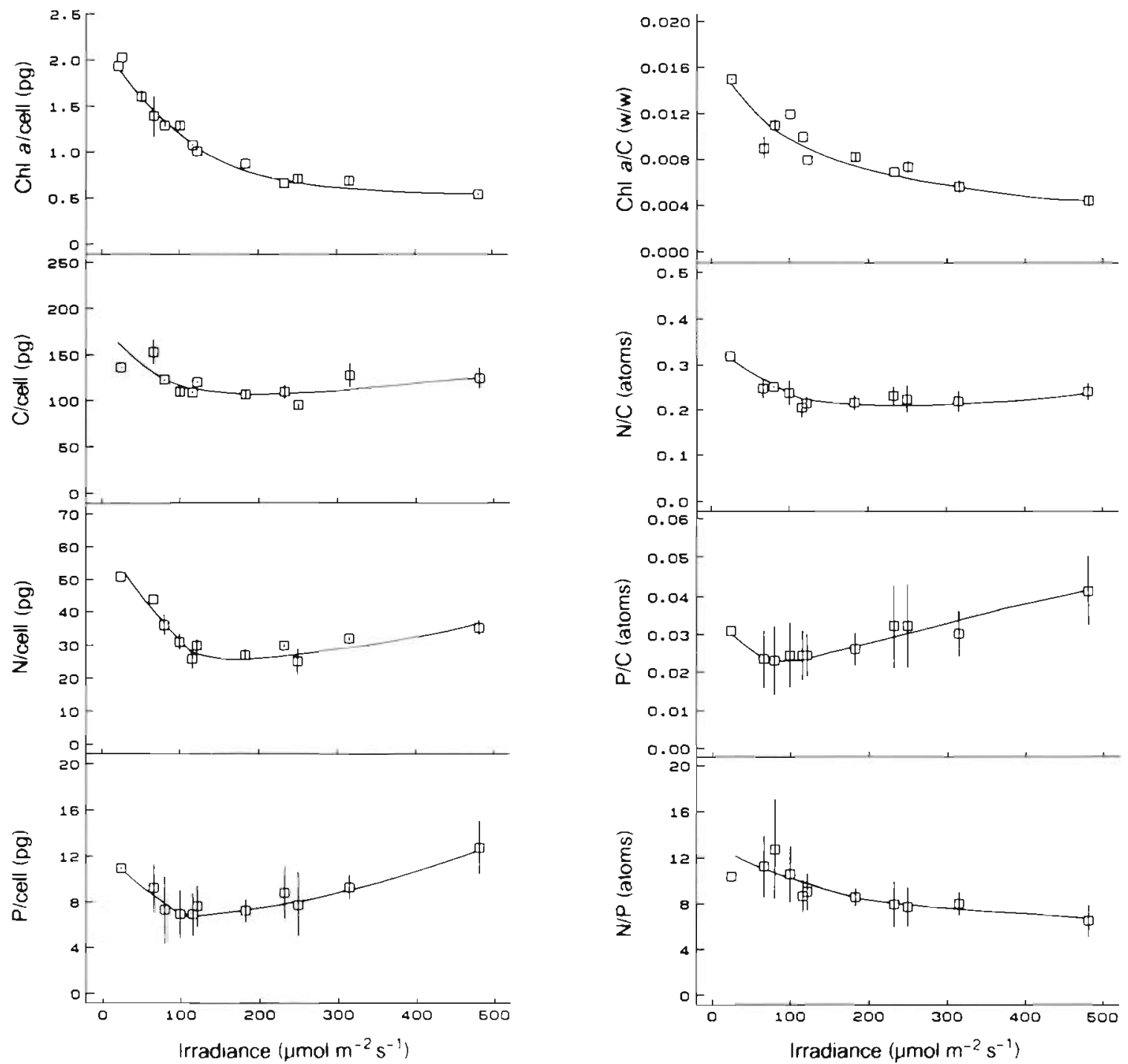

Fig. 2. Gymnodinium galatheanum. Cellular chl a, C, N, and $\mathrm{P}$, and the $\mathrm{chl}$ a/C, N/C, P/C and N/P ratios related to irradiance. $\mathrm{SE}$ indicated by vertical bars. Curves fitted by eye 
Table 1. Significance results of a regression analysis of irradi-

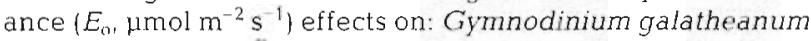
growth rate $(\mu) ;{ }^{\mu} p^{B} ;$ chl a/C ratio $(w / w) ;$ cellular $c h l a, C, N$ and $P$; and the N/C, P/C, and N/P ratios. The significance results are indicated for regressions using all irradiance data $\left(20 \leq E_{0} \leq 480 \mu \mathrm{mol} \mathrm{m} \mathrm{m}^{-2} \mathrm{~s}^{-1}\right)$, irradiances $\leq 120 \mu \mathrm{mol} \mathrm{m}^{-2} \mathrm{~s}^{-1}$, and irradiances $\geq 180 \mu \mathrm{mol} \mathrm{m} \mathrm{m}^{-2} \mathrm{~s}^{-1}$ Significance levels: $\cdots p<0.001$, ${ }^{*} p<0.01_{i} \cdot p<0.05 ;$ NS: not significant

\begin{tabular}{|c|c|c|c|}
\hline & $20 \leq E_{0} \leq 480$ & $E_{0} \leq 120$ & $E_{\mathrm{o}} \geq 180$ \\
\hline$\mu$ & $\cdots$ & & \\
\hline$\mu p^{B}$ & $\cdots$ & & \\
\hline $\mathrm{Chl} \mathrm{a/C}$ & $\cdots$ & & \\
\hline Chl a & $\cdots$ & & \\
\hline C & & - & NS \\
\hline $\mathrm{N}$ & & $\cdots$ & .. \\
\hline $\mathrm{P}$ & & NS & $\cdot$ \\
\hline $\mathrm{N} / \mathrm{C}$ & NS & $\cdots$ & NS \\
\hline $\mathrm{P} / \mathrm{C}$ & $\cdot$ & NS & NS \\
\hline$N / P$ & $\cdots$ & NS & NS \\
\hline
\end{tabular}

Table 1). The N/C ratio decreased significantly with increasing irradiance below $120 \mu \mathrm{mol} \mathrm{m} \mathrm{m}^{-2} \mathrm{~s}^{-1}$, but was approximately constant at higher irradiances; the $\mathrm{P} / \mathrm{C}$ and the N/P ratios increased and decreased significantly with increasing irradiance, respectively, between 20 and $480 \mu \mathrm{mol} \mathrm{m}{ }^{-2} \mathrm{~s}^{-1}$ (Fig. 2, Table 1).

\section{Effect of temperature and salinity}

A multiple regression of the specific growth rate $(\mu)$ on temperature $(T)$ and salinity $(S)$ yielded:

$$
\mu=0.073 T+0.027 S-0.002 T^{2}-0.0006 S^{2}-0.564
$$

The model is highly significant according to ANOVA $(p<0.001)$ and $83 \%$ of the variance is explained by the variables. Derivation of the model yields optimum tem-

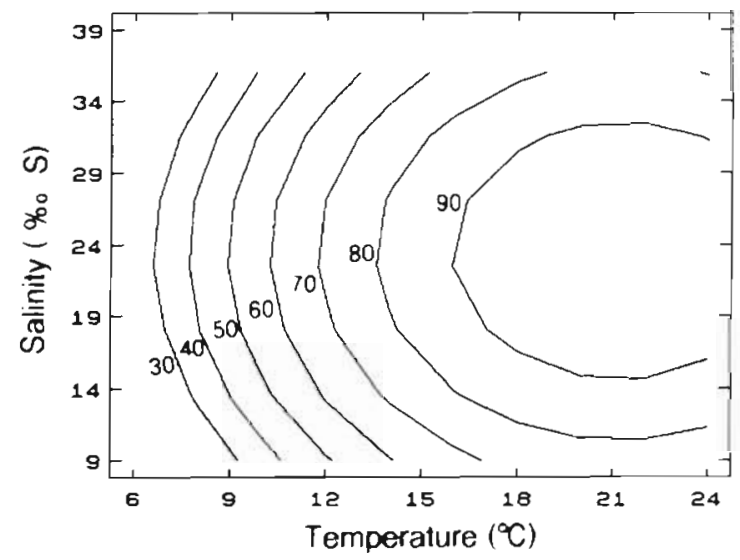

Fig. 3. Gymnodnium galatheanum. Response surface contours of the combined effect of temperature and salinity on growth rate $\left(d^{-1}\right)$. Numbers on figure indicate percentage of model-predicted optimum
Table 2. Gymnodnium galatheanum. Specific growth rate $\left(d^{-1}\right)$ under different combinations of temperature and salinity (SE indicated in parentheses)

\begin{tabular}{|c|c|c|c|c|c|}
\hline \multirow{2}{*}{$\begin{array}{c}\text { Salinity } \\
(\%)]\end{array}$} & \multicolumn{5}{|c|}{ Temperature $\left({ }^{\circ} \mathrm{C}\right)$ : } \\
\hline & 7 & 10 & 15 & 20 & 24 \\
\hline 10 & $\begin{array}{c}0.13 \\
(0.007)\end{array}$ & $\begin{array}{c}0.17 \\
(0.007)\end{array}$ & $\begin{array}{c}0.28 \\
\{0.020\}\end{array}$ & $\begin{array}{c}0.45 \\
(0.029)\end{array}$ & $\begin{array}{l}- \\
-\end{array}$ \\
\hline 14 & $\begin{array}{c}0.17 \\
(0.002)\end{array}$ & $\begin{array}{c}0.21 \\
(0.005)\end{array}$ & $\begin{array}{c}0.41 \\
(0.012)\end{array}$ & $\begin{array}{c}0.63 \\
(0.005)\end{array}$ & $\begin{array}{c}0.33 \\
(0.015)\end{array}$ \\
\hline 19 & $\begin{array}{c}0.18 \\
(0.002)\end{array}$ & $\begin{array}{c}0.27 \\
(0.007)\end{array}$ & $\begin{array}{c}0.48 \\
(0.002)\end{array}$ & $\begin{array}{c}0.57 \\
(0010)\end{array}$ & $\begin{array}{c}0.45 \\
(0.012)\end{array}$ \\
\hline 24 & $\begin{array}{c}0.17 \\
-\end{array}$ & $\begin{array}{c}0.25 \\
(.012)\end{array}$ & $\begin{array}{c}0.45 \\
(0.007)\end{array}$ & $\begin{array}{c}0.57 \\
(0.005)\end{array}$ & $\begin{array}{c}0.57 \\
(0.017)\end{array}$ \\
\hline 29 & $\begin{array}{c}0.18 \\
(0.012)\end{array}$ & $\begin{array}{c}0.22 \\
(0.002)\end{array}$ & $\begin{array}{c}0.41 \\
(0.007)\end{array}$ & $\begin{array}{c}0.56 \\
(0.005)\end{array}$ & $\begin{array}{c}0.51 \\
(0.017)\end{array}$ \\
\hline 34 & $\begin{array}{c}0.19 \\
(0.005)\end{array}$ & $\begin{array}{c}0.21 \\
(0.010)\end{array}$ & $\begin{array}{c}0.38 \\
(0.005)\end{array}$ & $\begin{array}{c}0.47 \\
(0.037)\end{array}$ & $\begin{array}{c}0.38 \\
(0.010)\end{array}$ \\
\hline
\end{tabular}

perature and salinity at $21^{\circ} \mathrm{C}$ and $23 \% \mathrm{~S}$, respectively and an optimum specific growth rate of $0.53 \mathrm{~d}^{-1}$ (Fig. 3). The measured maximum growth rate $\left(0.57 \mathrm{~d}^{-1}\right)$ was observed at 20 to $24^{\circ} \mathrm{C}$ and $24 \%$ S (Table 2).

The growth rate of Gymnodinium galatheanum was significantly affected by temperature $\left(7 \leq T \leq 24^{\circ} \mathrm{C}\right)$ and salinity $(10 \leq S \leq 34 \%$ S), according to the 2 factor analysis of variance (Table 3). No temperaturesalinity interaction was found for the growth rate. The carbon, nitrogen and phosphorus contents increased significantly at combinations of low temperature $\left(7,10^{\circ} \mathrm{C}\right)$ and low salinity $(10 \% \mathrm{~S})$; at higher salinities (14 to $34 \%$ S) carbon and nitrogen contents were independent of salinity, whereas the phosphorus content decreased significantly with increasing salinity (Fig. 4, Table 3). Carbon, nitrogen and phosphorus contents, however, decreased with increasing temperature; an

Table 3. Gymnodnium galatheanum. Significance results of an ANOVA of growth rate, cellular $\mathrm{C}, \mathrm{N}$ and $\mathrm{P}$, and the $\mathrm{N} / \mathrm{C}, \mathrm{P} / \mathrm{C}$ and N/P ratios on temperature $\left(7,10,15,20,24^{\circ} \mathrm{C}\right)$ and salinity $(10,14,19,24,29,34 \%$ S). Significance levels: $\cdots p<0.001, \cdots p<0.01, " p<0.05 ;$ NS: not significant

\begin{tabular}{|c|c|c|c|c|}
\hline Source of variation & $\mu$ & $\mathrm{C}$ & $N$ & $\mathrm{P}$ \\
\hline Temperature & $\cdots$ & $\cdots$ & .. & $\cdots$ \\
\hline Salinity & $\cdots$ & $\cdots$ & $\cdots$ & $\cdots$ \\
\hline Temperature & & $\cdots$ & . & $\because$ \\
\hline Salınity & & NS & NS & $\cdots$ \\
\hline Source of variation. & $\mathrm{N} / \mathrm{C}$ & & $P / C$ & $\mathrm{~N} / \mathrm{P}$ \\
\hline Temperature ${ }^{a}$ & * & & $\cdots$ & $\cdots$ \\
\hline Salinity $^{\circ}$ & NS & & $\cdots$ & $\cdots$ \\
\hline
\end{tabular}



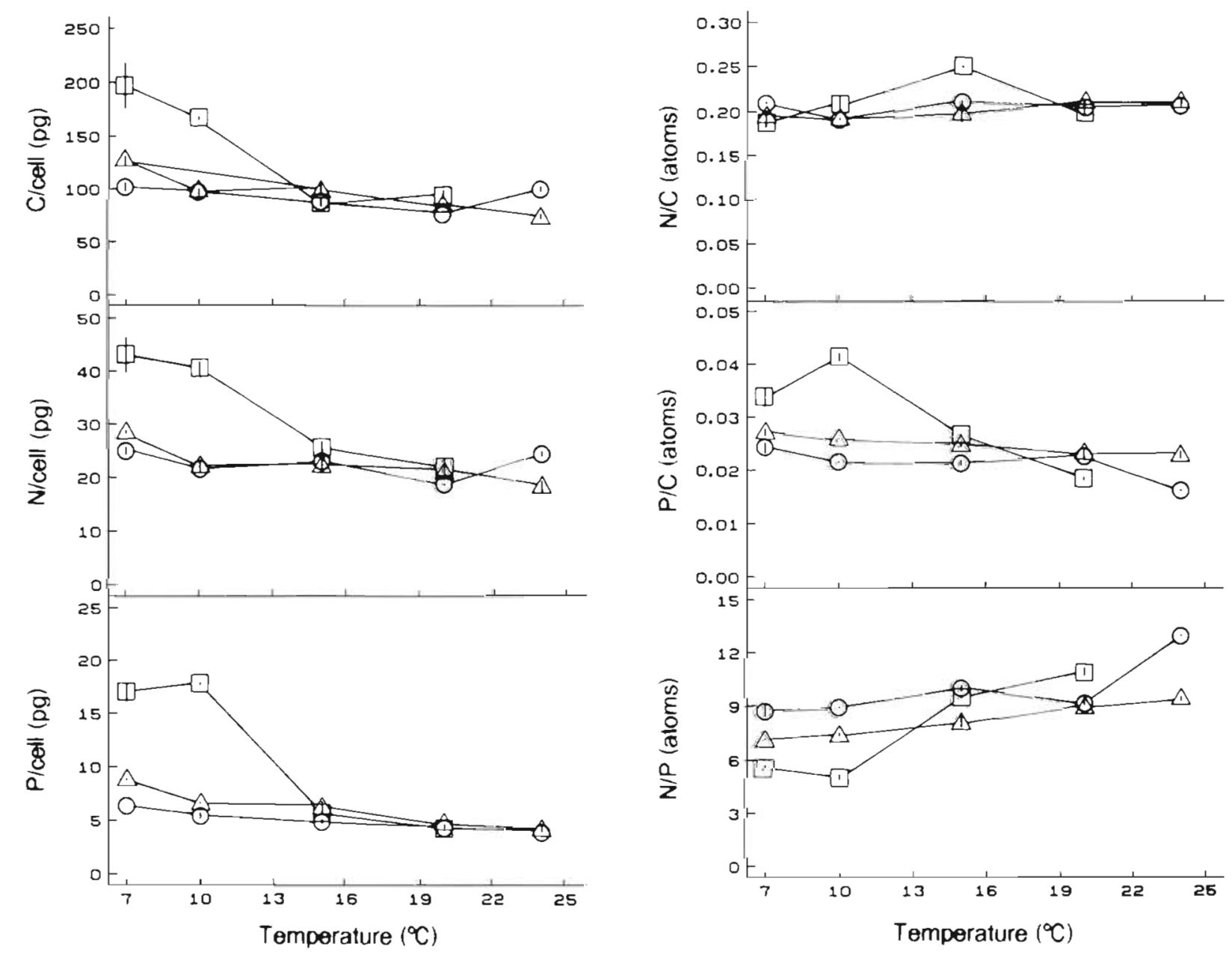

Fig. 4. Gymnodinium galatheanum. Effect of temperature and salinity on cellular $\mathrm{C}, \mathrm{N}$ and $\mathrm{P}$ and on N/C, P/C and N/P ratios. Data shown for the lowest and the highest salinity used and for the optimum salinity for growth: (D) $10 \%$, ( $\Delta$ ) $24 \%$, (O) $34 \%$. $\mathrm{SE}$ indicated by vertical bars

ANOVA on the total data set showed significant effects of both temperature and salinity on carbon, nitrogen and phosphorus (Fig. 4, Table 3). The ratios between cellular $\mathrm{C}, \mathrm{N}$ and $\mathrm{P}$ showed significant temperature effects; the $P / C$ and N/P ratios also varied significantly with the salinity, while the $\mathrm{N} / \mathrm{C}$ ratio was independent (Fig. 4, Table 3).

\section{DISCUSSION}

Gymnodinium galatheanum grew at all experimental temperatures $\left(7\right.$ to $24^{\circ} \mathrm{C}$ ) and salinities (10 to $34 \% \mathrm{~S}$ ), with optimum growth at high temperatures and moderate to high salinities, $\sim 17-24^{\circ} \mathrm{C}$ and $15-32 \% \mathrm{~S}$, respectively (Fig. 3). Differences in growth rate of $G$. galatheanum at identical cxpcrimental conditions $\left(15^{\circ} \mathrm{C}, 34 \% \mathrm{~S}, 255 \mu \mathrm{mol} \mathrm{m} \mathrm{m}^{-2} \mathrm{~s}^{-1}, 18 \mathrm{~h}\right.$ daylength) were found between the irradiance experiment $\left(0.28 \mathrm{~d}^{-1}\right)$ and the temperature/salinity experiment $\left(0.38 \mathrm{~d}^{-1}\right)$, possibly because the experiments were carried out at different times of the year and involved different batches of seawater. In addition, Johnsen \& Sakshaug (1993) reported G. galatheanum growth rates of $0.25 \mathrm{~d}^{-1}$ under conditions of $20^{\circ} \mathrm{C}, 34 \% \mathrm{~S}, 170 \mu \mathrm{mol} \mathrm{m} \mathrm{m}^{-2}$ $\mathrm{s}^{-1}$, and $12 \mathrm{~h}$ daylength

$\mu P_{m}^{B}$ for Gymnodinium galatheanum, $3.1 \mathrm{mg} \mathrm{C}(\mathrm{mg}$ chl a $)^{-1} \mathrm{~h}^{-1}$, is similar to the maximum ${ }^{\prime \prime} \mathrm{P}^{\mathrm{B}}$ found for Prorocentrum micans (Falkowsky et al. 1985; calculated from their Table 1), while ${ }^{\mu} P^{\mathrm{B}}{ }_{\mathrm{m}}$ for Gyrodinium aureolum $(0.82$; Nielsen 1992) is lower. Variation in ${ }^{\mu} P^{\mathrm{B}}$ among the 3 dinoflagellates is thus within a factor of 3.7. This variation is small compared to the variation in $P^{\mathrm{B}}$ found between different taxa (a factor of $10_{i}$ Geider 1993), which supports Geider's conclusion that $P_{\mathrm{m}}$ shows little variation within taxa compared to among taxa. Differences in ${ }^{\mu} P^{\mathrm{B}}$ are due to variations in both growth rate and chl $a / C$ ratio, and for the 3 species discussed above, variations in growth rate and chl a/C amount to factors of 1.6 and 6.3 , respectively. 
Most of the variation is thus accounted for by the chl a/C ratio.

The saturation irradiance at $15^{\circ} \mathrm{C}$ and $34 \% \mathrm{~S}$ for ${ }^{\mu} P^{\mathrm{B}}$ of Gymnodinium galatheanum ( $>500 \mu \mathrm{mol} \mathrm{m} \mathrm{m}^{-2} \mathrm{~s}^{-1}$ ) is higher than for maximum growth $\left(\mu_{\mathrm{m}} ; 120 \mu \mathrm{mol} \mathrm{m}^{-2}\right.$ $\mathrm{s}^{-1}$ ) (Fig. 1). This difference reflects the decrease in the $\mathrm{Chl}$ a/C ratio with increasing irradiance (Fig 2).

For Gymnodinium galatheanum the cellular contents of $\mathrm{C}, \mathrm{N}$ and $\mathrm{P}$ ranged from 72 to 197,17 to 51 and 4 to $17 \mathrm{pg} \mathrm{celI^{-1 }}$, respectively (Figs. 2 \& 4). Johnsen \& Sakshaug (1993) reported 43 to $62 \mathrm{pg} \mathrm{C}$ cell $^{-1}$ Cellular $C, N$ and $P$ reached minimum values around the saturation irradiance for growth $\left(120 \mu \mathrm{mol} \mathrm{m} \mathrm{m}^{-2} \mathrm{~s}^{-1}\right)$. At irradiances below the saturation irradiance for growth, cells became enriched with respect to $C, N$ and $P$ (Fig. 2). A similar trend has been found for Gyrodinium aureolum (Nielsen 1992) and Skeletonema costatum (Sakshaug \& Andresen 1986) and may be explained as an adaptive change to inactive, long-term viable stages. The irradiance relationships of cellular $\mathrm{C}, \mathrm{N}$ and $P$ were very similar; this is reflected in the ratios between the elements, with no significant differences found below and above the saturation irradiance for growth, except for the $\mathrm{N} / \mathrm{C}$ ratio where a significant increase was found with decreasing irradiance (Fig. 2 , Table 1)

The $\mathrm{N} / \mathrm{C}, \mathrm{P} / \mathrm{C}$ and $\mathrm{N} / \mathrm{P}$ ratios ranged from $0.18-0.32$, 0.016-0.041 and 5.0-11.3, respectively. These ratios are similar to those found for Gyrodinium aureolum, although the N/C ratio is slightly higher for Gymnodinium galatheanum. The $\mathrm{N} / \mathrm{C}$ ratio found in the present study $(\sim 0.19)$ is slightly higher than that $(0.15)$ reported by Paasche et al. (1984) at $20^{\circ} \mathrm{C}$ and $24 \% \mathrm{~S}$ and that $(0.15-0.19)$ reported by Johnsen \& Sakshaug (1993) under conditions of $20^{\circ} \mathrm{C}, 34 \% \mathrm{~S}, 30$ to $170 \mu \mathrm{mol}$ $\mathrm{m}^{-2} \mathrm{~s}^{-1}$ and $12 \mathrm{~h}$ daylength. Compared to the $\mathrm{P} / \mathrm{C}$ and $\mathrm{N} / \mathrm{P}$ ratios reported for other dinoflagellates (0.009-0.014 and 8-17, recalculated by converting organic phosphorus to total phosphorus by a conversion factor; see Table II in Sakshaug et al. 1984), the values for $G$. galatheanum indicate a high relative cellular phosphorus content and a large storage capacity for phosphorus.

The blooms of Gymnodinium galatheanum in Walvis Bay were associated with high surface temperatures compared with temperatures just outside the bay (Copenhagen 1953, Pieterse \& Van Der Post 1967). The blooms of $G$. galatheanum in the Oslofjord also occurred in years with high surface temperatures $(K$. Tangen pers. comm.). Thus temperature may be a regulating factor for blooms of $G$. galatheanum, as has been found for Gyrodinium aureolum (Nielsen \& Tønseth 1991).

Gymnodinium galatheanum successfully forms red tide blooms, as does the closely related Gyrodinium aureolum. Results from the present study add to the list of similarities between G. galatheanum and G. aureolum. Saturation irradiances for growth and for ${ }^{\mu} P^{B}$, respectively, are similar for $G$. galatheanum $(120$ and $>500 \mu \mathrm{mol} \mathrm{m} \mathrm{m}^{-2} \mathrm{~s}^{-1}$ ) and for $G$. aureolum (150 and $>400 \mu \mathrm{mol} \mathrm{m} \mathrm{m}^{-2} \mathrm{~s}^{-1}$ ) (Nielsen 1992), and their saturation irradiances for ${ }^{\mu} P^{B}$ are higher than found for many other dinoflagellates (Partensky \& Sournia 1986). Both species may survive for long periods (several months) in the stationary phase and both are able to accumulate large amounts of $\mathrm{P}$ compared to other dinoflagellates, an ability which may be important in bloom formation (Nielsen \& Tonseth 1991). The maximum growth rates are quite similar for the 2 species. Growth of $G$. galatheanum, however, is less sensitive to temperature-salinity changes, and it has a broader temperature-salinity tolerance range than does $G$. aureolum, which did not grow at $<10^{\circ} \mathrm{C}$ and $<12 \%$ S (Nielsen \& Tonseth 1991). Growth of $G$. galatheanum is not photoinhibited at irradiances $<500 \mu \mathrm{mol} \mathrm{m} \mathrm{m}^{-2} \mathrm{~s}^{-1}$ as is G. aureolum (Nielsen 1992). There may be a slight difference in the origin of the blooms; while the $G$. galatheanum blooms reported from the eutrophic Walvis Bay seems to arise in the bay, blooms of $G$. aureolum typically evolve offshore in tidal fronts where combinations of high nutrient levels and high temperature occur, and when conditions are suitable they are transported towards coastal areas (Nielsen \& Tonseth 1991). Given that these algae are physiologically alike, but that $G$. galatheanum is the hardier of the two, one would expect G. galatheanum blooms to be more frequent than $G$. aureolum blooms, assuming that initial stocks are present. Why this is not the case in North European waters is a question which still has to be answered.

\section{LITERATURE CITED}

Bjergskov T, Larsen J, Moestrup Ø. Sørensen HM, Krogh P (1990) Toksiske og potentielt toksiske alger i danske farvande. Fish Inspection Service, Ministry of Fisheries, Copenhagen

Bjørnland T, Tangen $K$ (1979) Pigmentation and morphology of a marine Gyrodinium (Dinophyceae) with a major carotenoid different from peridının and fucoxanthin. J Phycol 15:457-463

Braarud T (1959) A red water organism from Walvis Bay. Galathea Rep 1:137-138

Copenhagen WJ (1953) The periodic mortality of fish in the Walvis region. A phenomenon within the Benguela current. Department of Commerce and Industries, Division of Fisheries, Investigational Report 14:1-33

Dahl E, Yndestad M (1985) Diarrhetic shelfish poisoning (DSP) in Norway in the autumn 1984 related to the occurrence of Dinophysis spp. In: Anderson DM, White AW, Baden DG (eds) Toxic dinoflagellates. Proceedings of the Third International Conference on Toxic Dinoflagellates, St. Andrews, New Brunswick, Canada, June 8-12, 1985. Elsevier, New York, p 495-500 
Falkowsky PG, Dubinsky Z, Wyman K (1985) Growthirradiance relationships in phytoplankton. Limnol Oceanogr 30:311-321

Geider RJ (1993) Quantitative phytoplankton physiology: implications for primary production and phytoplankton growth. ICES Mar Sci Symp 197:52-62

Johnsen G, Sakshaug E (1993) Bio-optical characteristics and photoadaptive responses in the toxic and bloom-forming dinoflagellates Gyrodinium aureolum, Gymnodinium galatheanum, and two strains of Prorocentrum minimum. J Phycol 29:627-642

Keller MD, Selvin RC, Claus W, Guillard RRL (1987) Media for the culture of oceanic ultraphytoplankton. J Phycol 23 $633-638$

Koroleff F (1976) Determination of phosphorus. In: Grasshof K (ed) Methods of seawater analysis. Verlag Chemie, Weinheim, p 117-126

Larsen J, Moestrup $\varnothing$ (1989) Guide to toxic and potentially toxic marine algae. Institut for Sporeplanter, University of Copenhagen. Fish Inspection Service, Ministry of Fisheries, Copenhagen

Nielsen MV (1992) Irradiance and daylength effects on growth and chemical composition of Gyrodinium aureolum Hulburt in culture. J Plankton Res 14:811-820

Nielsen MV (1993) Toxic effect of the marine dinoflagellate Gymnodinium galatheanum on juvenile cod Gadus morhua. Mar Ecol Prog Ser 95:273-277

Nielsen MV, Stromgren T (1991) Shell growth response of mussels (Mytilus edulis) exposed to toxic microalgae. Mar Biol 108:263-267

Nielsen MV, Tønseth CP (1991) Temperature and salinity effect on growth and chemical composition of Gyrodinium aureolum Hulburt in culture. J Plankton Res 13:389-398

This article was submitted to the editor
Olsen Y, Østgaard K (1985) Estimating release rates of phosphorus from zooplankton: model and experimental verification. Limnol Oceanogr 30:844-852

Paasche E, Bryceson I, Tangen K (1984) Interspecific variation in dark nitrogen uptake by dinoflagellates. $J$ Phycol 20: $394-401$

Partensky F, Sournia A (1986) Le dinoflagellé Gyrodinium cf aureolum dans le plancton d l'Atlantique Nord: identification, ecologie, toxicité. Cryptogam Algol 7: 251-275

Pieterse F, Van Der Post DC (1967) The pilchard of South West Africa. Oceanographical conditions associated with redtides and fish mortalities in the Walvis Bay region. Administration of South West Africa Marine Research Laboratory $14: 1-125$

Platt T, Gallegos CL, Harrison WG (1980) Photoinhibition of photosynthesis in natural assemblages of marine phytoplankton. J Mar Res 38:687-701

Sakshaug E, Andresen K (1986) Effect of light regime upon growth rate and chemical composition of a clone of Skeletonema costatum from the Trondheimsfjord, Norway. J Plankton Res 8:619-637

Sakshaug E, Granelí E, Elbrächter M, Kayser H (1984) Chemical composition and alkaline phosphatase activity of nutrient-saturated and P-deficient cells of four marine dinoflagellates. J Exp Mar Biol Ecol 77:241-254

Steemann Nielsen E, Aabye Jensen E (1959) Primary oceanic production. The autotrophic production of organic matter in the oceans. Galathea Rep 1:49-136

Tangen K, Bjørnland T (1981) Observations on pigments and morphology of Gyrodinium aureolum Hulburt, a marine dinoflagellate containing 19'-hexanoyloxyfucoxanthin as the main carotenoid. J Plankton Res 3:389-401

Manuscript first received: September 14, 1995

Revised version accepted: January 24, 1996 